\title{
NUMERIKUS SZIMULÁCIÓS KUTATÁSOK AZ ÁRAMLÁS- ÉS HÖTECHNIKA TERÜLETÉN
}

\author{
Bolló Betti \\ egyetemi docens, Energetikai és Vegyipari Gépészeti Intézet, Aramlás- és Hötechnikai Gépek Intézeti Tanszéke \\ 3515 Miskolc, Miskolc-Egyetemváros, e-mail: aramzb@uni-miskolc.hu
}

\section{Fodor Béla}

tanszéki mérnök, Energetikai és Vegyipari Gépészeti Intézet, Áramlás-és Hötechnikai Gépek Intézeti Tanszéke 3515 Miskolc, Miskolc-Egyetemváros, e-mail: aramfb@uni-miskolc.hu

\begin{abstract}
Absztrakt
A Miskolci Egyetem Áramlás-és Hötechnikai Gépek Intézeti Tanszéke az elmúlt évtizedekben kutatási és fejlesztési feladatok keretében nagyon sok érdekes numerikus szimulációt készitett. Általában egy készülék elöállitása és mérése igen időigényes és költséges, a numerikus modellezés (CFD) azonban lehetővé teszi, hogy egy készülék áramlás és/vagy hötechnikai szempontból való megvizsgálása olcsóbb és gyorsabb legyen. A számitási eredmények kiértékeléséböl következtetni lehet arra, hogy hol kell például a geometriai kialakitáson változtatásokat végrehajtani, hogy minél jobb berendezést készithessünk. A numerikus szimuláció az ipar szinte minden területén alkalmazható, ahol felmerülnek áramlástechnikai és höátviteli problémák. Jelen cikkben a Tanszéken-CFD szimuláció alkalmazásával - kidolgozott néhány kutatási és fejlesztési feladatot mutatunk be.
\end{abstract}

Kulcsszavak: numerikus szimuláció, tüzeléstechnikai berendezés, forgó gépek, háztartási készülékek.

\begin{abstract}
The Department of Fluid and Heat Engineering at the University of Miskolc has been very popular with research and development work on numerical simulation over the past decades. Generally, the construction and measurement of a device is very time consuming and costly, but numerical modeling (CFD) allows it to be cheaper and quicker to test a device for flow and/or thermal engineering. From evaluating of the computational it can be deduced where to make changes to the geometry, for example, in order to make the best possible equipment. Numerical simulation is applicable in almost all areas of the industry where flow and heat transfer problems arise. This article describes some of the Department's research and development works using CFD simulation.
\end{abstract}

Keywords: numerical simulation, firing equipment, rotating machines, household appliances.

\section{Bevezetés}

Az áramlás- és hőtechnikai feladatok numerikus vizsgálatára a numerikus folyadékdinamika (Computational Fluid Dynamics: „CFD”) módszereit alkalmazzák. A CFD a folyadékáramlás, a hőtranszport, a hozzá kapcsolódó kémiai reakciók és egyéb jelenségek alkotta rendszerek számítógépes szimulációkon alapuló vizsgálatát jelenti [1]. A technika fejlődése és a megkívánt gazdasági szempontok, valamint az energiafelhasználás mind a gyártás, mind az üzemeltetés szempontjából a berendezések fejlesztését követeli meg, ezért az ipar számára elengedhetetlen a felsorolt szempontok 
figyelembevétele. A numerikus szimuláció a termelési- és üzemeltetési folyamat bármely szakaszába beilleszthető. A CFD vizsgálatok a mindennapi élet számos területén alkalmazhatók úgy, mint az energetika, vegyipar, épületgépészet, környezettechnika, jármüipar stb.

A numerikus áramlástani (CFD) vizsgálat számos esetben az egyetlen lehetőség arra, hogy a 3D-s áramlások részleteiről is információkat kapjunk. A jelenleg rendelkezésre álló mérőeszközök ugyanis nem minden esetben teszik lehetővé a teljes áramlási tér feltérképezését. A numerikus modellezés segítségével azonban lehetővé válik, hogy például egy forgógép belső terében kialakuló áramlási teret megvizsgáljunk. A CFD vizsgálat további előnyei közé tartozik az is, hogy a geometriai változtatások jóval könnyebben végezhetők el, mint a mérési összeállítás esetében, ahol új próbadarabot kell legyártani az újabb mérésekhez.

A szoftverpiacon található néhány CFD kereskedelmi kód (pl. Ansys Fluent, Comsol, Creo, Numeca, OpenFoam), amely alkalmas áramlás- és hőtechnikai problémák numerikus megoldására. A szoftverkínálat azonban korántsem olyan széles e területen, mint amit a szilárdtest mechanikában széles körben ismert véges elemek módszer alkalmazása jelent. A CFD módszerek alkalmazása területén tapasztalt lemaradás azzal magyarázható, hogy a CFD problémákat általában nehezebb megoldani, ezért a CFD kódok csak lassabban váltak elfogadottá az ipari felhasználók számára.

A Miskolci Egyetem Áramlás- és Hőtechnikai Gépek Intézeti Tanszéke az elmúlt évtizedekben nagyon sokféle ipari kutatási és fejlesztési feladattal találkozott, aminek a megoldásához numerikus szimulációt alkalmazott. Az ipari munkák nagy részét az ún. Ansys Fluent kereskedelmi forgalomban kapható programcsomaggal végezte el, amely a véges térfogatok módszerére épülő hő- és áramlástechnikai feladatok elvégzésére alkalmas szoftver. A Tanszék 2002 óta rendelkezik a programcsomaggal, amelyhez folyamatosan megvásárolta a frissítéseket.

Jelen cikkben a Tanszék kutatási és fejlesztési, illetve ipari munkáiból mutatunk be néhány nagyobb tématerületet úgy, mint a kemencék, reaktorok, háztartási hütőberendezések, porszívók modellezése és a forgógépek numerikus szimulációja.

\section{Tüzeléstechnikai berendezések modellezése}

Egyik nagy témakör a tüzeléstechnikai berendezések numerikus modellezése. Az első nagyobb megbízást a TÜKI Rt. adta, amikor egy kemence tüzterében kialakuló hőmérséklet- és sebességeloszlásra voltak kíváncsiak különböző égők esetén. A kemence háromdimenziós geometriai modelljének felhasználásával két égőtípus esetén 3-3 bevezetett levegő térfogatáramnál meghatároztuk a fütés nélküli üres kemencetérben kialakuló sebességeloszlást (un. hideg üzemállapot). A számítási eredményeket összehasonlítottuk a TÜKI Rt. által végzett pontbeli sebességmérések adataival. A vonatkozó számítások ellenőrzése, illetve paraméterrendszerének beállítása céljából ugyanis elengedhetetlen a mért és a számított sebességterek egybevetése. [2]

A mért és számított értékek alapján elkészítettük a kemence egyszerüsített geometriai modelljét, amely tartalmazza a hőkezelendő acéltuskót is. A kemencét két egymástól eltérő fütési program szerint fütöttük fel (instacionárius modell). Figyeltük a változó fütés hatására mind a kemencetérben, mind pedig az acéltuskóban felmelegedés hatására változó hőmérsékletmezőt (1. ábra (a)). A lángot a fütési programnak megfelelő mennyiségü, de állandó hőmérsékletű forró levegővel modelleztük. A számított pontbeli melegedési görbéket összehasonlítottuk a TÜKI Rt. által hasonló körülmények között, de méréssel meghatározott görbékkel. [3,4]

Az általános tapasztalatok kialakításához végzett további szimulációk első lépéseként, vizsgálatunk tárgya egy úgynevezett „,szakaszos adagolású” kísérleti kemence volt, amelybe egy darab, szúrólángot 
szolgáltató, NM típusú gázégő került beépítésre a kemence egyik oldalfalába. E kemence esetén két eltérő (folyamatos és szakaszos) tüzelési programok esetén modelleztük a teljes hőkezelési folyamatot.

Második lépésként úgynevezett „,kocsizó” kísérleti kemencét vizsgáltunk, ahol két darab, SW típusú, lapos lángot szolgáltató gázégő került beépítésre a kemence boltozatába, a kemence hossztengelyében. A kemencébe épített két gázégő a kemence alja felé fordítva üzemelt. A boltozatba épített gázégők által szolgáltatott lapos, szétterülő láng a kemenceteret és a boltozatot melegítette intenzíven (1. ábra (b)). A kemence padlójára helyezett acél próbadarab a kemence légterében áramló forró gázok konvektív hőátadása, a lángsugárzás és a boltozatról, valamint a falakról érkező sugárzás révén melegedett. Az első esetén csak egy égő üzemelt, betét nem volt a kemencében és a kialakult stacioner állapot volt a vizsgálat tárgya, míg a második esetben kétégős üzem mellett történt a teljes hőkezelési folyamat modellezése. [5]

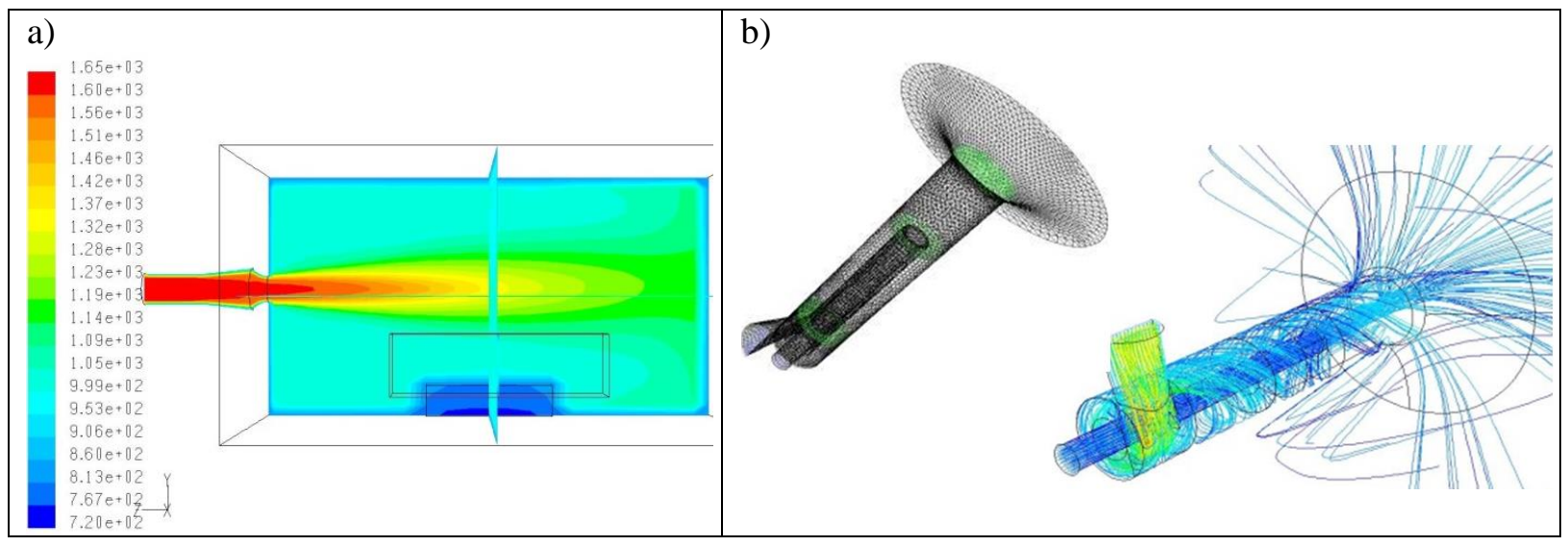

1. ábra. a) Hömérséklet-eloszlás a gázégö síkjában $\left[{ }^{\circ} \mathrm{C}\right][4]$, b) Gázégö hálókialakitása, illetve a gázégöben lévö áramvonalak [5].

Az Anyagtudományi Intézet és a Kémiai Tanszékkel közösen vizsgáltuk egy pirolízis kemence konvekciós zónájában észlelt korróziós és eróziós károsodásokat. Az Áramlás- és Hőtechnikai Gépek Tanszékének feladata a konvekciós zónában kialakuló hőmérséklet- és sebességeloszlás modellezése volt [6]. A 2. ábra látható, hogy a pirolízis kemence geometriai kialakítása nem egyszerü, összesen 4 darab csőkígyó helyezkedik el a kemencében. A feladatot nehezítette, hogy a felső vezetéken beérkező szénhidrogénhez az alsó csővezeték előtt forró gőzt adagolnak és úgy folytatja az útját az alsó csővezeték szakaszon keresztül, azaz az áramlás kétfázisú volt. A bonyolult geometria miatt nehéz volt a hálózás, több milliós lett az elemszám, ami növelte a számítási időt. A Tanszéken 2007-ben rendelkezésre álló számítógépén 3 hónap futási időre volt szükség, mire elvégeztük a számításokat.

A Tanszék foglalkozott ezenkívül elektromosan fütött kemencék modellezésével [7, 8], valamint egy nanografitot előállító reaktor áramlás- és hőtani analízisével is.

\section{Háztartási hütőberendezések modellezése}

A háztartási hütőberendezések hozzátartoznak a mindennapi élethez. Egy hűtőgép egy átlagos család áramfogyasztásának közel harmadáért felel, ezért is fontos, hogy energia-hatékony legyen. A hủtőberendezés fogyasztása nagymértékben függ a hủtő nagyságától, elhelyezkedésétől, a használat módjától, de hütőgépünk teljes élettartamát és jövőbeni költségeit mindenekelött az energiaosztályba való besorolása határozza meg. A hütőberendezések igen nagy számban készülnek, és erős a konkurenciaharc. 
A gyártók célja ezért az, hogy a lehető legjobb hatásfokú hütő előállítása a lehető legolcsóbban, vagyis az anyagfelhasználás minél kevesebb, a gyártási technológia pedig a lehető legegyszerübb legyen.

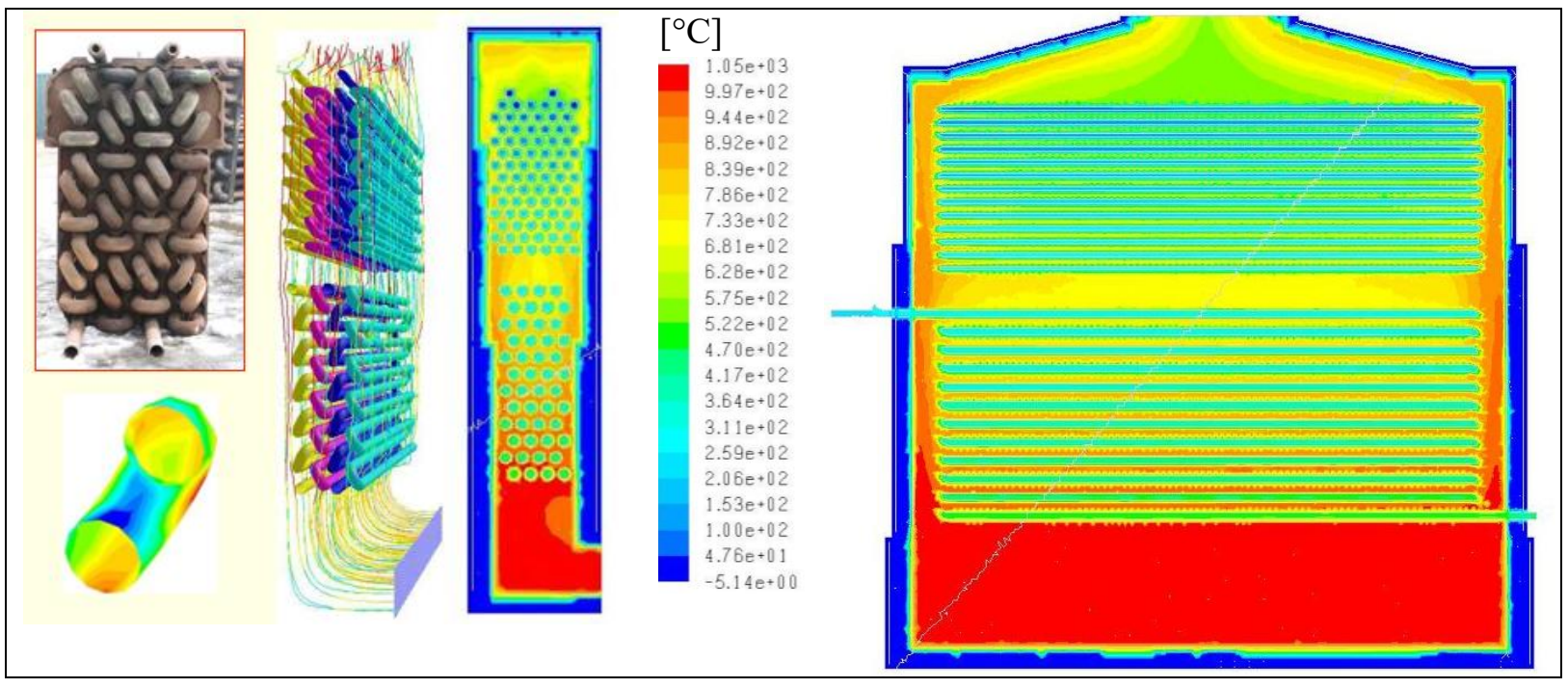

2. ábra. A pirolízis kemencében lévö csőkígyó közötti áramvonalak, illetve a középsíkokban a hömérséklet-eloszlás [6].

A hütőgép belső terében méréssel meg lehet határozni néhány pontban a hőmérsékletértékeket, de a hütő teljes belső terében kialakuló hőmérséklet- illetve sebességeloszlásról csak sejtésünk van, mérni nem lehetséges. A kutatási cél ezért a hütőszekrényben lezajlódó hőátviteli- és áramlási folyamatokat megismerése numerikus modellezés segítségével.

A Tanszék több hütőberendezés vizsgálatával is foglalkozott, amelyekben elsősorban a kialakuló hőmérséklet- és sebességeloszlás meghatározása volt a cél, de emellett a következő vizsgálatokat is el kellett végezni:

- A Tanszék elvégezte egy üres és egy vizsgálócsomagokkal terhelt fagyasztóláda modell teljes lehütési-felmelegedési ciklusának áramlás- és hőtechnikai vizsgálatát. A vizsgálat során meghatározta a hütött teret határoló falban a hőmérséklet-eloszlást, a környezetből a hütött térbe érkező hőáramot, továbbá a fagyasztóláda belső terében kialakuló sebesség és hőmérséklet teret. [9]

- Különböző típusú abszorpciós hűtőszekrény esetén a teljes hülési folyamat modellezése. A hűlés során meghatározásra került az elvont hő, valamint a szigetelt falakon beáramló hő. A vizsgálatok során különböző kisebb-nagyobb geometriai átalakítások hatásának elemezésével is foglalkoztunk. $[9,10]$

- Üres hűtőszekrényben létrejövő hő- és áramlási folyamatok finomstruktúrájának meghatározása. A hütőben elhelyezett üvegpolcok áramlást gátló hatásának vizsgálata, illetve a hütő hátlapján elhelyezett elpárologtató mentén létrejövő intenzíven leáramló hideg levegő elemzése. A kapott egyenetlen hőmérséklet-eloszlásból következtetni lehet arra, hogy hőtechnikai átalakítások (elpárologtató kialakítása), vagy/és a polcrendszer átjárhatóvá tételével mennyivel javítható a hő- és sebességeloszlás egyenletessége. [11]

- Egy zárt fagyasztószekrény esetén felmerül a kérdés, hogy mi történik akkor, ha az ajtó gumitömítésének elöregedése miatt, vagy a hütőgép fém burkolatának nem kellö összeillesztésénél egy kis résen keresztül környezeti levegő jut a burkolat és az ajtó közé. Ekkor a levegő az ajtó gumitömíté- 
sének illeszkedésénél beáramolhat a hütőtérbe. A fagyasztóba kerülő melegebb levegőből a nedvességtartalom kicsapódik a hideg falra, melynek következtében a hütő jegesedni kezd. Ezért öt különböző rés esetén megvizsgáltuk, hogy a jegesedésért valóban a réseken beáramló levegő a felelös-e (3. ábra). A kiszámolt sebesség- és hőmérsékletmezők egyértelmüen igazolták, hogy a jegesedés döntően - a mérési tapasztalatokkal egyezően - a hütő felső részén következik be a rés helyétöl függetlenül. [12]

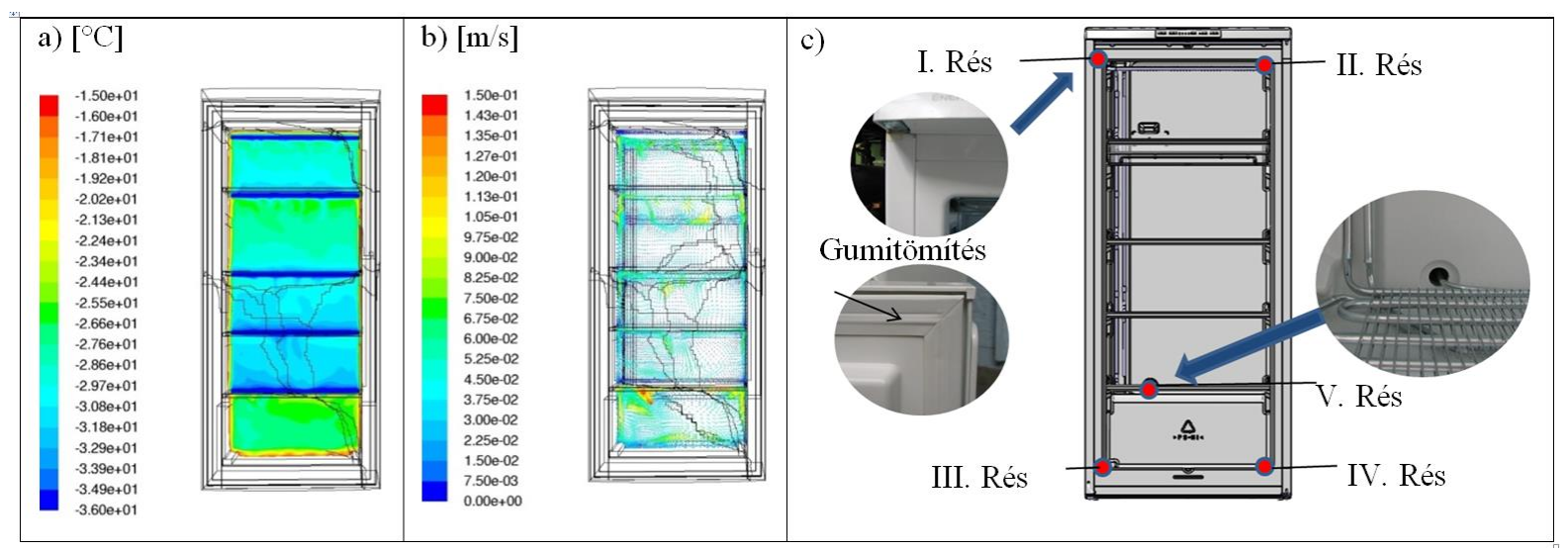

3. ábra. Fagyasztószekrény belső terében a) a hömérséklet-és b) a sebességeloszlás; c) Rések elhelyezése [12].

\section{Háztartási porszívó modellezése}

A háztartási porszívók esetén fontos kutatási cél a gépek hatásfokának növelése és zajszintjének csökkentése. A porszívó belső áramlási csatornájában az áramlás mentén a levegő belső súrlódásából, a falsúrlódásból, az áramlás falról való leválásából, kialakuló örvényekből, hirtelen irányváltásokból, keresztmetszet-változásból stb. adódóan energiaveszteség lép fel, amely a levegő hasznosítható energiatartalmát csökkenti. E csökkenés mértékének redukálásával az áramlás fenntartásához szükséges energia csökken, a szállítás hatásfoka nő. A cél ezeknek a veszteségforrásoknak a feltárása, ezért a veszteség- és zajforrások feltérképezésére a porszívó légszállító rendszerének teljes hosszán számításokat és méréseket végeztünk (4. ábra). A kapott eredményekből következtetni tudtunk arra, hogy hol kell az áramlási ellenállás és a zajterhelés csökkentésére a geometrián változtatásokat végrehajtani. A megváltoztatott geometrián numerikus szimuláció segítségével további kísérletsorozatokat végeztünk a porszívó zajcsökkentő és porleválasztó elemeinek a porszívó zajszintjére és hidraulikai ellenállására gyakorolt hatásának meghatározására. [13-15]

\section{Forgó gépek modellezése}

A lakossági energiafelhasználás növekedése miatt egyre jobban elötérbe kerülnek a mindennapi életben használatos gépek energia felvételének csökkentésére irányuló vizsgálatok. Ezen gépek használatára jellemző üzemi paraméterek meghatározására szabványban rögzített mérési módszereket használhatunk. Az elmúlt évtizedekben az iparban jelentős igény merült fel a számítógéppel segített tervezés (Computer Aided Design) sokoldalú felhasználásán túl az úgynevezett kapcsolt numerikus vizsgálatok alkalmazására. A numerikus szimulációk a szóban forgó berendezések prototípus gyártása előtt hóna- 
pokkal, akár évekkel korábban elkezdődnek annak érdekében, hogy a legkisebb költségen és energia befektetés árán a lehető legoptimálisabb kialakításban kerüljön legyártásra a termék.

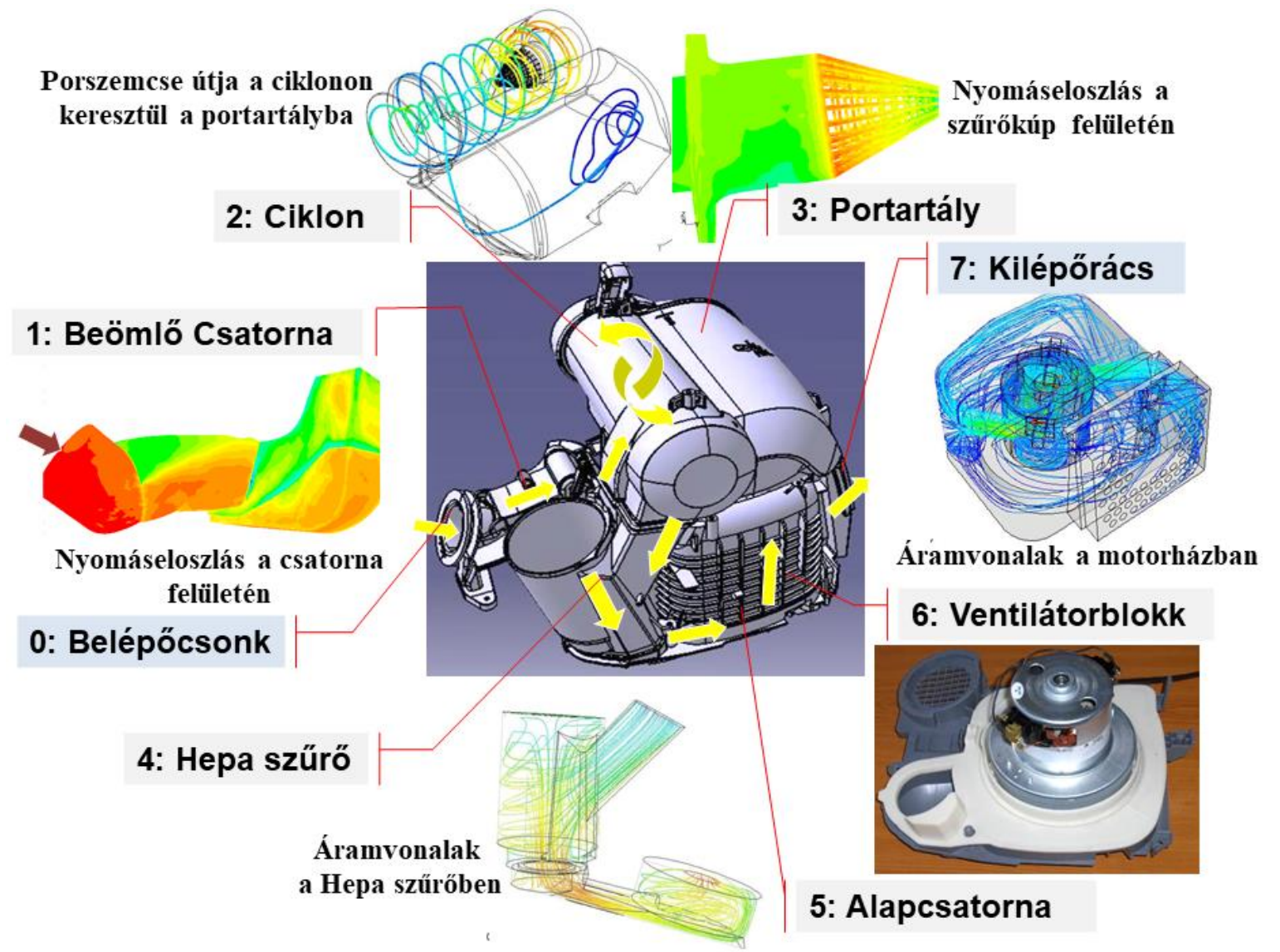

4. ábra. A porszivó légszállitó rendszerének bemutatása [13-15].

Az áramlás- és hőtechnikai feladatokat ellátó forgó berendezések úgy, mint a ventilátorok, szivatytyúk és turbinák, kompresszorok többnyire egy speciális geometriával kialakított úgynevezett járókerék található, melynek feladata a folyadék energiatartalmának megváltoztatása. A forgó gép müködéséből adódóan és sok esetben az igen nagy, vagy éppen a meglehetősen kicsiny valós geometriai méretek miatt nehéz az áramlás jellegére vonatkozó lokális következtetéseket levonni. Leginkább csak a legfontosabb üzemi jellemzők állíthatók elő mérés vagy számítás segítségével. A numerikus szimuláció lehetővé teszi, hogy a forgó gépekben részletesebben megvizsgáljuk az áramlási teret. A járókerék geometriai felülete a gép jellegétől függően különböző előzetes számítások segítségével adható meg. A határoló görbék háromdimenziós térfogatokká való átalakítását közvetett CAD rendszer segítségével hoztuk létre, például egyfokozatú kéziszerszám ventilátor, porszívó fúvó, illetve Kaplan turbina esetén is [16-20].

A szimuláció kezdeti- és peremfeltételeit a rendszerre jellemző paraméterekből, többnyire feltételezhető valóságos üzemi jellemzők alapján határoztuk meg. Ezek a paraméterek szoros kapcsolatban vannak a numerikus megoldóval, beállításuk mikéntje a számítás ,jóságát” is befolyásolja. Az elvégzett szimulációk üzemi és paramétertartománya igen széles. Például a jellemző fordulatszám porszívó 
fúvóinál 40000 1/min [21] (5. ábra), vízturbina esetén [22] 1000...3000 1/min, de kéziszerszámok vagy autóipari ventilátorok esetén 5000...10000 1/min [23]. A kapott eredmények többnyire az áramlási mező megismerésére korlátozódnak, így a szimulációból az idő függvényében egyes előre definiált keresztmetszetek átlagnyomás, -sebesség, -sürüség, illetve a tömegáramai állíthatók elő [2427]. Szükség esetén számíthatók erőhatások és globális üzemi paraméterek is.

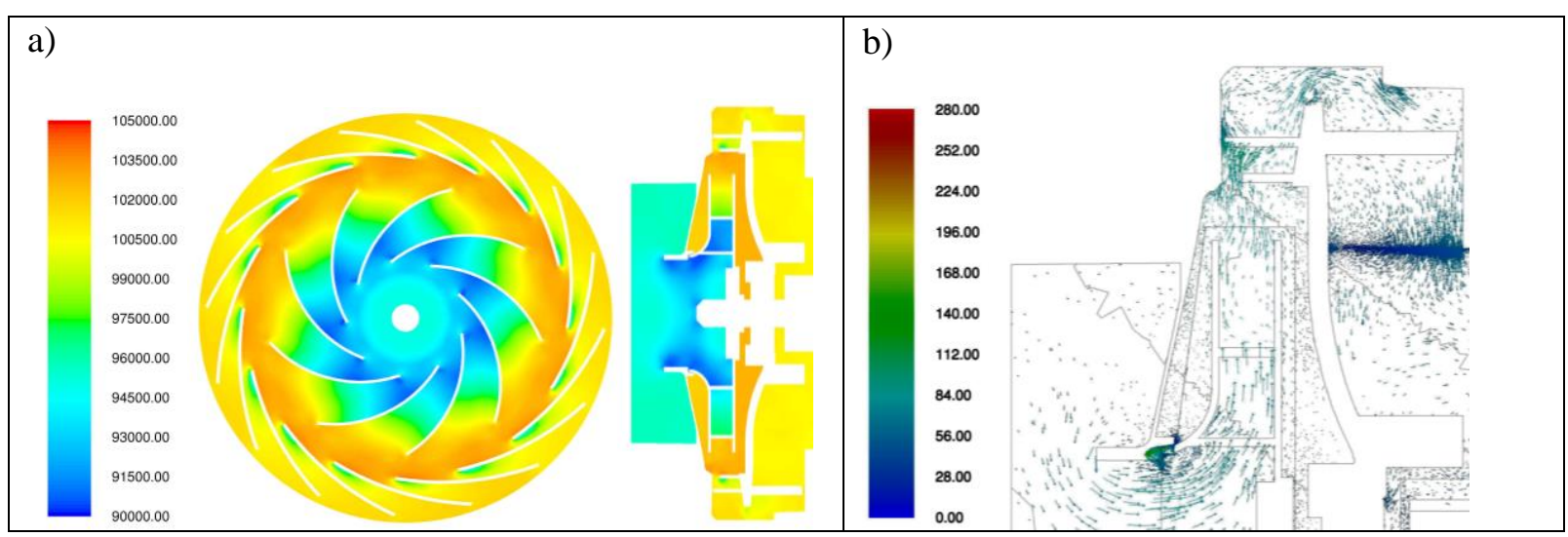

5. ábra. A fúvóaggregát egyik metszetében a) a nyomáseloszlás; és b) a sebességeloszlás.

\section{6. Összefoglalás}

A kutatási és fejlesztési munkáink során alkalmazott numerikus modellezés segítségével kapott eredmények alkalmasak a vizsgált berendezések teljes belső terében az áramlás- és hőtani jellemzők, és ezáltal a transzportjellemzők változásából eredő jelenségek bemutatására, amely laboratóriumi mérés alkalmazásával nem, vagy csak nagyon nehezen végezhető el. Egy termékfejlesztés során könnyebben ellenőrizhető, hogy a geometriai méreteknek, anyagoknak stb. megváltoztatása milyen hatást gyakorol a berendezés sebesség- és hömérsékletterére, illetve a határoló felületeken a környezetből érkező hőáram értéke is meghatározható, ami nagyon fontos lehet tüzeléstechnikai berendezéseknél, illetve hütőbútoroknál. A numerikus szimuláció lehetőséget biztosít arra, hogy ha szükséges kiegészítsük saját felhasználói kóddal, amit például a hütőszekrény lehülési folyamatához, vagy a szakaszos tüzelésủ kemence gázégőjének müködtetéséhez alkalmaztunk.

Jelen cikkben a Tanszék kutatási munkájának csak egy kis szeletét mutattuk be, a felsorolt feladatokon kívül foglalkoztunk hőcserélők, üzemcsarnokok, medencék, füstgázcsatornák, álló és rezgő körhenger stb. modellezésével is.

\section{Köszönetnyilvánítás}

A cikkben ismertetett kutató munka az EFOP-3.6.1-16-2016-00011 jelü „Fiatalodó és Megújuló Egyetem - Innovatív Tudásváros - a Miskolci Egyetem intelligens szakosodást szolgáló intézményi fejlesztése" projekt részeként - a Széchenyi 2020 keretében - az Európai Unió támogatásával, az Európai Szociális Alap társfinanszírozásával valósul meg. 


\section{Irodalom}

[1] Ferziger, J. H., Peric, M.: Computational Methods for Fluid Dynamics, Springer, 1999. https://doi.org/10.1007/978-3-642-98037-4

[2] Gyulai, L., Zámborszky, B., Szabó, Sz.: Investigation of flow and heat transfer processes in furnaces by using numerical simulation. Proc. 18th MicroCAD, International Scientific Conference, Section D, Miskolc, Hungary, (2004), pp. 37-42.

[3] Benke, M., Gyulai, L., Szabó, Sz.: Kísérleti kemencébe helyezett acéltuskó hevítésének instacionér szimulációja tüzelési program esetén. XXXIX. Ipari szeminárium, Budapest, Magyarország, Energiagazdálkodási Tudományos Egyesület (2004) pp. CD.

[4] Benke, M., Gyulai, L., Szabó, Sz.: Kísérleti hőkezelő kemencébe helyezett acél próbadarab felfütésének numerikus szimulációja. XL. Ipari szeminárium, Budapest, Magyarország, Energiagazdálkodási Tudományos Egyesület (2005) pp. CD.

[5] Benke, M., Szabó, Sz., Frank, J.: Determination of the optimal fuel-air ratio in an industrial preheater. Proc. 4th International PhD Conference On Mechanical Engineering, Plzen, Czech, (2006) pp. 9-10.

[6] Mertinger, V., Benke, M., Szabó, Sz., Bánhidi, O., Bolló, O., Kovács, Á.: Examination of a failure detected in the convection zone of a cracking furnace. Engineering Failure Analysis 18 (2011) pp. 1675-1682. https://doi.org/10.1016/j.engfailanal.2011.02.003

[7] Zámborszky, B., Tolvaj, B.: Hőkezelő alagútkemence hőtechnikai modellje. XXXIX. Ipari szeminárium. Dunaújváros, Magyarország, (2004) pp. CD.

[8] Bolló, B., Janiga, G., Szabó, Sz.: Modelling of units of an electrically heated furnace. Proc. 20th MicroCAD, International Scientific Conference, Section E, Miskolc, Hungary, (2006) pp. 1-6.

[9] Szabó, Sz., Tolvaj, B., Bolló, B., Tóth, R.: Hütőgépek áramlás- és hőtechnikai analízise numerikus szimulációval. Miskolci Egyetem Közleményei - 2. sorozat Anyag- és Kohómérnöki Tudományok 1 (3) (2007) pp. 149-157.

[10] Tóth, R., Benke, M., Tolvaj, B., Szabó, Sz.: Abszorpciós hütőszekrényben kialakuló áramlás- és hőmérsékletmező numerikus szimulációja. Doktoranduszok Fóruma: Gépészmérnöki és Informatikai Kar szekciókiadványa, Miskolc, Magyarország (2006) pp. 222-227.

[11] Bolló, B., Nagy, J., Szabó, Sz.: Hűtőszekrényben lezajló áramlás- és hőtechnikai folyamatok analízise numerikus szimulációval. $\mathrm{K}+\mathrm{F}$ eredmények összefoglalása: GOP-1 .1 .2-08/1-20080002. Miskolc, Magyarország (2012) pp. 105-110.

[12] Bolló, B., Nagy, J., Szabó, Sz.: Tömítetlenségek hatása fagyasztószekrényekben kialakuló áramlási és hőmérsékletviszonyokra. XII. Magyar Mechanikai Konferencia, Miskolc, Magyarország (2015) pp. 216-222.

[13] Lippai, G.: Computational simulation of the flow in an Electrolux Callisto-type vacuum cleaner from its inlet to the outlet of dust container. Diploma Thesis, University of Miskolc, Miskolc, Hungary (2007).

[14] Tóth, R., Szabó, Sz.: Noise Analysis of Vacuum Cleaner. Proc. 21th MicroCAD, International Scientific Conference, Section E, Miskolc, Hungary, (2007) pp. 119-123.

[15] Bolló, B., Szabó, Sz., Soltész, L.: Zajforrás- és veszteségfeltárás laboratóriumi mérés és numerikus szimuláció alkalmazásával háztartási készülék fejlesztéséhez. Elektronikus Müszaki Füzetek 11 (2012) pp. 473-482.

[16] Fodor, B., Kalmár, L., Takács, Gy.: Schaufelrad von axialen Turbine darstellt in CAD-Systemen mit der Anwendung der hydraulischen Rechnungen. Proc. 19th MicroCAD, International Scientific Conference, Section F, Miskolc, Hungary (2005) pp. 9-16. 
[17] Fodor, B., Kalmár, L., Takács, Gy.: Axiális átömlésủ vízgépek lapátozásának CAD rendszerekben való ábrázolása a hidraulikai tervezés eredményeinek felhasználásával. XIII. Nemzetközi Gépész Találkozó, OGÉT, Kolozsvár, Románia (2005) pp. 139-143.

[18] Fodor, B., Czibere, T., Kalmár, L., Pap, E.: Näherungsberechnung der betrieblichen Schaufelbelastung von Kaplan-Turbinen. Proc. 20th MicroCAD, International Scientific Conference, Miskolc, Magyarország (2006) pp. 13-20.

[19] Fodor, B., Kalmár, L.: Axiális vízturbina hidraulikai tervezése és CFD szimulációjának előkészítése. OGÉT, XV. Nemzetközi Gépész Találkozó (2007) pp. 114-117.

[20] Fodor, B.: Számítógéppel segített szimulációs környezet kialakítása ventilátorok esetén: Configuring computer aided simulation environment in case of fans. OGÉT, XIX. Nemzetközi Gépészeti Találkozó, Kolozsvár, Románia (2011) pp. 1-4.

[21] Kalmár, L., Szabó, Sz., Janiga, G., Fodor, B., Soltész, L.: Characterization of different one-stage blower designs using three-dimensional unsteady numerical flow simulation. Polska Akademia Nauk Instytut Maszyn Prezeplywowych, Poland (2014) 126 pp. 55-64.

[22] Fodor, B., Kalmár, L., Bencs, P.: Hydraulic design of Kaplan water turbine blade threedimensional body model. International Conference on Innovative Technologies: IN-TECH, Faculty of Engineering University of Rijeka, Croatian (2017) pp. 213-216. Paper: ISSN 01849069

[23] Fodor, B.: Numerical investigation of the flow in a radial bladed ventilator impeller: Radiális lapátozású ventilátor járókerék áramlástechnikai vizsgálata. OGÉT, XVII. Nemzetközi Gépészeti Találkozó, Cluj-Napoca, Románia (2009) pp. 1-4.

[24] Kalmár, L., Fodor, B.: CFD Investigation of the Flows in One-Stage Blower Aggregate, 2013 Proc. 5th Int. Conf. Computational Mechanics and Virtual Engineering, COMEC 2013, Transilvania University of Brasov, Romania (2013) pp. 197-202.

[25] Fodor, B., Kalmár, L.: Turbófúvó aggregátban kialakuló áramlás numerikus vizsgálata. OGÉT, XXI Nemzetközi Gépészeti Találkozó, Kolozsvár, Románia (2013) pp. 118-121.

[26] Fodor, B., Kalmár, L.: Fluid and heat engineering numerical analysis of the flow in a turbo blower aggregate. Annals of Faculty of Engineering Hunedoara -Int. Journal of Engineering XII. (2), (2014) pp. 219-224.

[27] Dorogi, D., Bolló, B., Szabó, Sz.: Effects of external disturbances on the performance of an axial cooling fan. Review of Faculty of Engineering Analecta Technica Szegedinensia (2019) 13 pp. 48-55. https://doi.org/10.14232/analecta.2019.1.48-55 